\title{
An empirical retrospect of the impacts of government expenditures on economic growth: new evidence from the Nigerian economy
}

\author{
Stephen Taiwo Onifade ${ }^{1}$, Savaş Çevik', Savaş Erdoğan ${ }^{1}$, Simplice Asongu ${ }^{2,3}$ and Festus Victor Bekun $4,5^{*}$ (])
}

\author{
*Correspondence: \\ fbekun@gelisim.edu.tr \\ ${ }^{4}$ Faculty of Economics \\ Administrative and Social \\ Sciences, Istanbul Gelisim \\ University, Istanbul, Turkey \\ Full list of author information \\ is available at the end of the \\ article
}

\begin{abstract}
The impacts of public expenditures on economic growth have been revisited in this paper with respect to capital expenditure, recurrent expenditure and the government fiscal expansion in line with support for the budgetary allocations to various sectors in the context of the Nigerian economy. Pesaran's ARDL approach has been applied to carry out the impact analysis using annual time-series data from 1981 to 2017. Empirical findings support the existence of a level relationship between public spending indicators and economic growth in Nigeria. Incisively, recurrent expenditures of government were found to be significantly impacting on economic growth in a negative way while the positive impacts of public capital expenditures were not significant to economic growth over the period of the study. Further results from the Granger Causality Test reveal that fiscal expansion of the government that is hinged on debt financing is strongly granger causing public expenditures and domestic investment with the latter also Granger causing real growth in the economy. We, therefore, provide some important policy recommendations following the results of the empirical analysis.
\end{abstract}

Keywords: Nigeria, Fiscal policies, Economic growth, Debt to GDP ratio, ARDL models

\section{Introduction}

Following the aftermath of the Great Economic Depression of the 1930s that culminated in the birth of the Keynesian Economics School of thought, the attention of a significant number of nations has been drawn to the relevance of government involvement in stabilizing and regulating aggregates of the general economy. That development was in contrast to the prevailing classical view about the working principles of the invisible hands of demand and supply that interplay to create necessary adjustments in relation to output determination and employment (Johnson et al. 2001; Shaikh 2009; Backhouse 2015).

There are two major categories of economic policies that have been widely utilized over a vast period of time for the general purpose of economic stabilization and for the achievement of some essential macroeconomic goals and objectives in specific terms. These policies are fiscal and monetary. Although the two policies are different 
in terms of their structure and the application of their fundamental instruments, however, they are generally targeted at achieving similar goals and objectives of maintaining economic stability in most nations (Beetsma and Jensen 2005; Claeys 2006). While the latter is generally a formidable instrument in the hands of the apex bank of various nations, the former exists as an important economic instrument in the hands of the governments of various nations.

Fiscal policies are government policies that are strategically designed to regulate or stabilize the economy through various forms of taxes and expenditures. They are economic policies that integrate government strategies for generating revenue basically via taxation and its subsequent strategies for making decisions on how the corresponding revenue that is generated would be allocated for attaining targeted economic goals. According to Jhingan (1997), fiscal policy aims at ensuring long-run economic stability by the adjustments of short-run economic fluctuations in such a way that a government uses its expenditure and revenue programs to generate desirable effects while avoiding those effects that are undesirable on a nation's income production, and employment levels.

There are various factors that might be contributing to incremental public expenditures in many nations based on empirical evidences. Hong and Nadler (2015) identified growing sources of government revenue as one major factor that could contribute to incremental public expenditures. Some other studies like Remmer (2004), Ouattara (2006) and Asongu and Jellal (2016) have also shown that factors like access to foreign aid and grants could as well promote incremental public expenditure and this is often witnessed in the majority of low-income countries.

The role of the Nigerian government in economic activities has grown enormously and the challenges that public policymakers face are increasing day by day. Public expenditures have been growing continuously over the years and more especially in the last two decades. The total of both capital and recurrent expenditure of the government grew sporadically from about $\$ 60.25$ billion (about $\$ 7.49$ bn) in 1990 to about $\$ 3.99$ trillion (\$39.07 bn) in 2010 (CBN 2017).

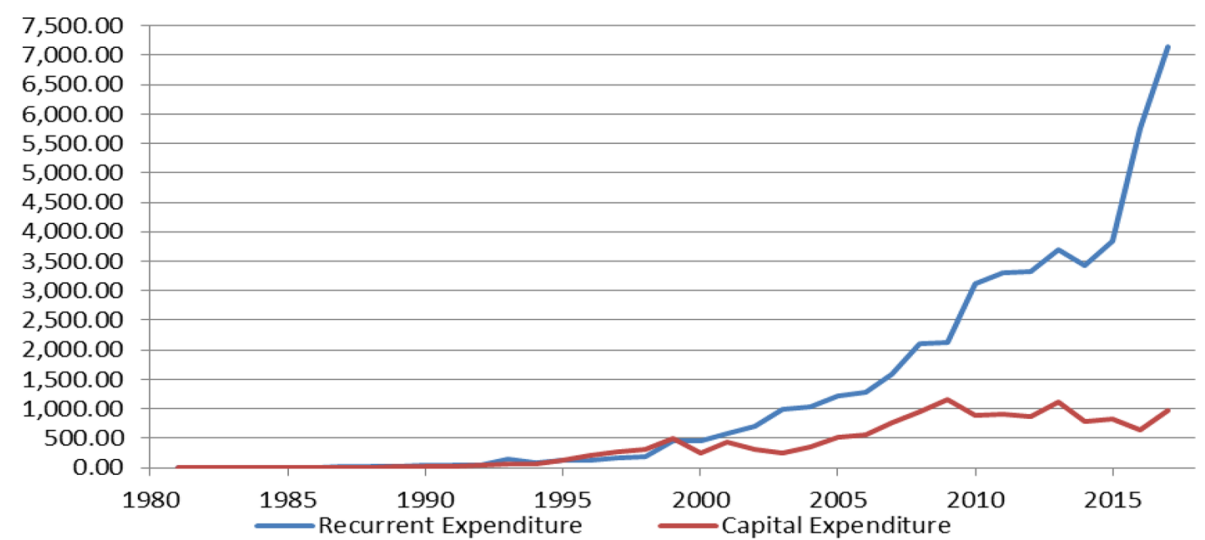

SOURCE: Authors computation from CBN data (2017) 
Huge chunks of the Nigerian federal government expenditure have been channeled into recurrent expenditure over the years due to some factors such as expansion in size of the civil service and disproportionate emoluments for political office holders among others. Recurrent expenditure grew from $\$ 36.21$ billion (about $\$ 4.5$ bn) in 1990 to about \#3.109 trillion (about $\$ 20.68$ bn) by the year 2010. Capital expenditures also witnessed some changes during these periods as the total capital expenditure grew at a decreasing rate from 24.04 billion (about $\$ 2.9$ bn) in 1990 to 234.45 billion (about $\$ 2.29$ bn) in 2000 and as at 2010, capital expenditure has risen to $\$ 883.87$ billion (about $\$ 5.88$ bn). However, as of 2010, recurrent expenditures alone accounted for over $75 \%$ of the total government expenditures (CBN 2017).

There is no doubt with regards to the pattern of transformation that public spending has witnessed over the years in Nigeria. However, the question of whether these increments in public spending have translated into desired economic growth and prosperity of the people is still yet to be answered. Cases of corruption and mismanagement of public funds have stalled the chances of making adequate budget appropriation and execution of capital projects and this has left the country in a state of huge infrastructural gaps thereby, creating a cog in the wheels of the nation's economic growth. Furthermore, there have been changes in the dynamics of the demand for public services with respect to the demographic explosion that has generated more pressure on the available insufficient social amenities. Shelton (2007) noted that growing population and problems associated with urbanization often exacerbate the pressure for the government to increase public expenditures.

Earning revenue is very important, at the same time; we are of the opinion that channeling the revenue to create the right impact on the economy by achieving desirable macroeconomic goals and objectives is a more paramount matter that needs to be addressed. Thus, this study re-examines the impacts of government spending on economic growth in the Nigerian economy context while considering the divergent opinions from the existing literature. Furthermore, the study also provides more insight into the government expenditure-led growth literature that hinges partly on debt financing in relation to the private sector spending effect in the economy.

The rest of the study is structured as follows. Section 2 provides insights into expansionary and contractionary fiscal policies while the attendant literature is covered in Sect. 3. The methodology and data are discussed in Sect. 4, whereas Sect. 5 discloses the empirical results. Section 6 concludes with implications are future research directions.

\section{Efficiency of fiscal policies: the expansionary and contractionary approaches}

Fiscal policies often come in either of expansionary or contractionary forms when the government wishes to effectively regulate or manage the level of aggregate demand in any economy. The expansionary fiscal policy is applied when the government wishes to stimulate aggregate demand and this is often visible when the government increases expenditures on projects in the various sectors of the economy or when it lowers tax burdens while paving the way for higher disposable income for its citizens in addition to some transfer payments. The major rationale behind this is the multiplier effect which holds that public spending could help to stimulate private spending and tackle the challenges associated with economic recession thereby boosting economic growth 
as popularly demonstrated by the Keynesian economic school of thought as documented in the attendant literature (Cwik and Wieland 2010; Auerbach and Gorodnichenko 2012; Jaramillo and Cottarelli 2012).

However, there are concerns about the opinion that the expansionary fiscal policy could exacerbate inflationary pressure and in some situations, higher government spending may not create the desired stimulus on economic growth, but rather lead to an undesirable or negative impact on growth: a scenario often referred to as the crowdingout effect. The public sector can exercise undue advantage over the private sector in capital accumulation and when the government aims at expanding expenditure by boosting tax revenue via higher taxes, this may become a disincentive to private sector investment (Barro 1990; Afonso and Sousa 2011). Furthermore, expansionary policies may also pave the way for excessive deficit financing since experiences have shown that several nations resort to borrowing in order to sustain the execution of various public projects. Shonchoy (2010) noted that higher public debt could reduce private sector confidence due to the need for debt servicing which might exacerbate tax burden on the private sector and thus engender a detrimental effect on economic growth and productivity in the long run. Sawyer (2012) noted that future generations should be prevented from the burden of unsustainable debt by tackling the deficit in public finance and strengthening private sector confidence thereby helping to sustain growth and employment in the medium term. In the interest of these related views on debt financing, various studies have focused on determining optimum debt levels vis-à-vis the economic sizes of nations and have come out with different ratios. These include the work of Reinhart and Rogoff (2010) with the finding that a debt to GDP ratio that exceeds 90\% can slow down growth and the work of Cecchetti et al. (2011) which suggests a debt to GDP ratio of $85 \%$ for 18 Organisation for Economic Co-operation and Development (OECD) member countries.

On the other hand, the contractionary fiscal policies are geared towards downsizing and regulating excess in aggregate demand. They are often applied when inflationary pressure is seen to be posing a dangerous threat to economic stability and in some circumstances when prevailing levels of public expenditures have risen to the point of crowding out the private sector efficiency. In such situations, government expenditures are generally scaled-down with the implementation of various austerity measures especially to reduce the overall recurrent expenditures and transfer payments with a possible increase in tax revenue. However, there are also arguments indicating that some contractionary fiscal policies may not produce the expected results as they could also exacerbate economic crisis by creating more disruptions on the growth path (Jaramillo and Cottarelli 2012; Dellepiane-Avellaneda 2015).

\section{Literature review}

Available empirical evidence on the impacts of government spending on growth have revealed that the subject matter is still very open to more discussion as existing results vary from one place to another. The variation in the evidence could be explained by various factors ranging from the peculiarity of the series of fiscal policy reforms that each country implemented over a period of time to the choice of the methodology that researchers adopt in their studies. 
Cooray (2009) identified government size which is a function of public expenditure as an important factor that affects economic growth. Günalp and Gür (2002) noted that the size of government is positively associated with economic growth and that the overall impacts of government spending are positive and quite large especially in the case of developing nations. Empirical findings from Bose et al. (2007) and Baldacci et al. (2008) have established a significant positive impact of public capital expenditures on the economic growth of some developing economies within a disaggregated analysis framework. Yasin (2011) using panel data estimation techniques obtained a significant positive impact of government expenditures on the economic growth of some group of Sub-Saharan African countries. Alexiou (2009) obtained a significant positive impact of government spending on capital formation combined with some other factors like private investment and trade openness on economic growth in the case of countries in southeast Europe. Nwaka and Onifade (2015) have also obtained a positive nexus between the size of the government and economic growth in some African countries.

Although there are overwhelming empirical evidences supporting the positive effect of government spending on economic growth, nevertheless, there are other empirical findings that have supported the contrary about the same relationship. Guseh (1997) obtained a result that is an indication of the case where government spending can negatively affect economic growth in an empirical study that was carried out on some middle-income countries. Growing public expenditures on some specific sectors of an economy may also serve as a disincentive to economic growth. For instance, Abu-Bader and Abu-Qarn (2003) have obtained a result showing that larger government spending on the military slows down economic growth in the cases of Syria, Egypt, and Israel. In addition, some studies have also come up with the findings that no causal relationship exists between government spending and economic growth such as the work of Oteng-Abayie (2011) for some West African countries.

Usman et al. (2011) from their study obtained a result showing that public expenditure has no impact on economic growth in Nigeria. However, their findings further support the existence of a long-run relationship between public expenditure and economic growth in the country. Egbetunde and Fasanya (2013) working on data from 1970 to 2010, concluded that the total expenditure of the government has a negative impact on growth in Nigeria with only recurrent expenditures showing some little positive impacts. Okoro (2013) noted that there is an existence of dynamic changes in the nature of the impacts of government expenditure on economic growth in Nigeria with respect to capital and recurrent expenditure on the short-run and long-run bases. Fölster and Henrekson (2001) have noted that a proper address of the methodological process helps in providing a better understanding of the relationship between public expenditure and economic growth. Thus, this present study re-examines the subject matter by considering the divergent opinions from the existing literature within a framework that allows more dynamic adjustment in estimation procedures, in contrast to the methodological approaches that have been used in extant studies.

\section{Methodology and data}

The Auto-Regressive Distributed Lag (ARDL) approach was applied for the empirical analysis of this study using annual time-series data from 1981 to 2017 covering a period of 37 years. Economics growth was proxied by real gross domestic product of 
the country over the period of the study. Government expenditure in Nigeria comprises government capital and recurrent expenditures which can further be broken down into all public spendings on administrations, economic and social services, and other transfers. The breakdown of government expenditures is often reported in the annual statistical bulletin of the Central Bank of Nigeria (CBN). Over the years, government revenue has remained grossly insufficient to support adequate budget implementation due to various factors including fluctuations or plunge in oil prices and low tax revenue at all tiers of government. Consequently, we factor-in government debt into the analysis as significant components of the expansionary government expenditures have been augmented to a large extent by borrowings and this is evident by the rise in public debt from both domestic and external sources over the years. One of the common arguments that is often made in support of continuous expansionary fiscal policies in many nations is that government expenditures do not only have the capacity to stimulate economic growth but in addition, they often create some multiplier effects on private spendings and domestic investment which ultimately help in boosting economic growth. A simple model representation to capture the relationships among our variables is as follows:

$$
\mathrm{RGDP}=\beta_{0}+\beta_{1} \mathrm{RECEXP}+\beta_{2} \mathrm{CAPEXP}+\beta_{3} \mathrm{DEBT}+\beta_{4} \mathrm{PRIEXP}+\beta_{5} \mathrm{INVEST}+\mu_{t},
$$

where RGDP is the real gross domestic product; RECEXP is the total government recurrent expenditures as a percent of GDP; CAPEXP is the total government capital expenditures as a percent of GDP; DEBT is the total public debt as a percent of the GDP; PRIEXP is the private consumption expenditure; INVEST is the gross domestic investment as measured by annual growth of gross capital formation.

All variables are in natural logarithm form except the gross domestic investment. From Eq. (1) the $\beta_{0}$ represents the intercept parameter and $\beta_{1}, \beta_{2}, \beta_{3}, \beta_{4}$, and $\beta_{5}$ represent the slope parameters that measure the impacts of the independent variables on the dependent variable and the error term is denoted by $\mu_{t}$. Data were sourced from the statistical bulletin of the CBN, World Development Indicators (WDI 2018) and the International Monetary Fund (IMF 2019).

Consistent with contemporary literature (Asongu et al. 2019a), the auto-regressive distributed lag (ARDL) model as developed by Pesaran and Shin (1999) and further extended by Pesaran et al. (2001) is known to be widely applicable for the analysis of time-series data regardless of the order of integration provided that none of the underlying variables are integrated in the second order, as denoted by I(2).

\section{Empirical results}

As a precautionary measure and in order to ascertain the suitability of our choice of methodology based on the nature of each data, building on contemporary literature (Asongu 2014; Asongu et al. 2019b), a stationarity test was conducted on each variable using the Augmented Dickey-Fuller (ADF) and Phillips-Perron (PP) unit root tests and the results are provided in Table 1.

From the unit root results, real gross domestic product (RGDP), total government recurrent expenditures as a percent of GDP (RECEXP), total government capital expenditures as a percent of GDP (CAPEXP), total public debt as a percent of the GDP 
Table 1 Unit root test

\begin{tabular}{|c|c|c|c|c|c|c|}
\hline (Level) & RGDP & RECEXP & CAPEXP & DEBT & PRIEXP & INVEST \\
\hline$G_{E}(A D F)$ & 0.7938 & 0.3268 & 0.5196 & 0.2849 & 0.7673 & 0.2114 \\
\hline$C_{E}(A D F)$ & 0.9096 & 0.4686 & 0.8847 & 0.3998 & 0.1381 & $0.0208^{* *}$ \\
\hline$N_{\mathrm{E}}(\mathrm{ADF})$ & 0.9996 & 0.2510 & 0.2807 & 0.4998 & 1.0000 & $0.0060^{* * *}$ \\
\hline$G_{E}(P P)$ & 0.3562 & 0.3276 & 0.5196 & 0.4138 & 0.6993 & $0.0016^{* * *}$ \\
\hline$C_{E}(P P)$ & 0.9911 & 0.5014 & 0.7210 & 0.5110 & 0.1381 & $0.0004^{* * *}$ \\
\hline$N_{\mathrm{E}}(\mathrm{PP})$ & 1.0000 & 0.2101 & 0.1969 & 0.5915 & 1.0000 & $0.0000^{* * *}$ \\
\hline (1st Diff) & $\Delta \mathrm{RGDP}$ & $\Delta$ RECEXP & $\Delta$ CAPEXP & $\Delta$ DEBT & $\Delta$ PRIEXP & $\Delta$ INVEST \\
\hline$G_{E}(A D F)$ & $0.0196^{* *}$ & $0.0000^{* * *}$ & $0.0000^{* * *}$ & $0.0430^{* *}$ & $0.0007^{* * *}$ & $0.0000^{* * *}$ \\
\hline$C_{E}(A D F)$ & $0.0018^{* * *}$ & $0.0000^{* * *}$ & $0.0000^{* * *}$ & $0.0083^{* * *}$ & $0.0003^{* * *}$ & $0.0000^{* * *}$ \\
\hline$N_{\mathrm{E}}(\mathrm{ADF})$ & $0.0250^{* *}$ & $0.0000^{* * *}$ & $0.0000^{* * *}$ & $0.0004^{* * *}$ & $0.0037^{* * *}$ & $0.0000^{* * *}$ \\
\hline$G_{E}(P P)$ & $0.0192^{* *}$ & $0.0000^{* * *}$ & $0.0000^{* * *}$ & $0.0616^{*}$ & $0.0007^{* * *}$ & $0.0000^{* * *}$ \\
\hline$C_{E}(P P)$ & $0.0018^{* * *}$ & $0.0000^{* * *}$ & $0.0000^{* * *}$ & $0.0121^{* *}$ & $0.0003^{* * *}$ & $0.0000^{* * *}$ \\
\hline$N_{E}(\mathrm{PP})$ & $0.0250^{* *}$ & $0.0000^{* * *}$ & $0.0000^{* * *}$ & $0.0007^{* * *}$ & $0.0042^{* * *}$ & $0.0000^{* * *}$ \\
\hline
\end{tabular}

The superscripts ${ }^{* * *},{ }^{* *}$ and ${ }^{*}$ represent the rejection level at $1 \%, 5 \%$ and $10 \%$ levels of significance, respectively. $\Delta$ denotes first difference operator. Also, RGDP means, real gross domestic product; RECEXP is, total government recurrent expenditures as a percent of GDP; CAPEXP represents, total government capital expenditures as a percent of GDP; DEBT is total public debt as a percent of the GDP; PRIEXP, denotes private consumption expenditure; INVEST, gross domestic investment as measured by annual growth of gross capital formation. Also, $G_{E}$ represents the unit root test model for a random walk variable with both drift and trend parameters; $C_{E}$ is the model with a drift parameter only while $N_{E}$ is a very restricted model to conduct unit root test without a drift and trend. The $t$-statistics values of the ADF and PP tests were reported

(DEBT), and private consumption expenditure (PRIEXP) are non-stationary variables at level but at first difference implying that they are I(1) variables while gross domestic investment(INVEST) was stationary at level meaning that it is an $\mathrm{I}(0)$ variable. The ARDL representation of the relationship among our variables is provided in Eq. (2) as follows:

$$
\begin{aligned}
\Delta \mathrm{RGDP}_{t}= & \gamma_{0}+\gamma_{1} \operatorname{RGDP}_{t-1}+\gamma_{2} \operatorname{RECEXP}_{t-1}+\gamma_{3} \operatorname{CAPEXP}_{t-1}+\gamma_{4} \mathrm{DEBT}_{t-1} \\
& +\gamma_{5} \mathrm{PRIEXP}_{t-1}+\gamma_{6} \operatorname{INVEST}_{t-1}+\sum_{i=1}^{p} \alpha_{1} \Delta \mathrm{RGDP}_{t-i} \\
& +\sum_{i=0}^{q} \alpha_{2} \Delta \operatorname{RECEXP}_{t-i}+\sum_{i=0}^{q} \alpha_{3} \Delta \mathrm{CAPEXP}_{t-i}+\sum_{i=0}^{q} \alpha_{4} \Delta \mathrm{DEBT}_{t-i} \\
& +\sum_{i=0}^{q} \alpha_{5} \Delta \operatorname{PRIEXP}_{t-i}+\sum_{i=0}^{q} \alpha_{6} \Delta \operatorname{INVEST}_{t-i}+\varepsilon_{t}
\end{aligned}
$$

where all the variables remained as earlier defined. The $\left(\alpha_{1}, \alpha_{2}, \alpha_{3}, \alpha_{4}, \alpha_{5}, \alpha_{6}\right)$ represent the short-run parameters while the $\left(\gamma_{1}, \gamma_{2}, \gamma_{3}, \gamma_{4}, \gamma_{5}, \gamma_{6}\right)$ denote the long-run parameters.

In order to examine the existence of a long-run relationship between our variables and real gross domestic product, we applied the ARDL bound test approach to co-integration. The test is conducted using the critical values of the bound test for both the upper and lower bounds as provided by Pesaran et al. (2001). The null hypothesis $\left(H_{0}\right)$ that $\left(\gamma_{1}=\gamma_{2}=\gamma_{3}=\gamma_{4}=\gamma_{5}=\gamma_{6}=0\right)$ is tested against the alternative hypothesis that $\left(\gamma_{1} \neq \gamma_{2} \neq \gamma_{3} \neq \gamma_{4} \neq \gamma_{5} \neq \gamma_{6} \neq 0\right)$. The result of the bound tests for the $\operatorname{ARDL}(2,2,0$, $2,1,0)$ as selected by the AIC is provided in Table 2 . 
Table 2 Bounds test to co-integration

\begin{tabular}{llll}
\hline Equations & Lags (AIC) & F-statistics & Decision \\
\hline$(2)$ & 2 & 6.57 & Co-integration \\
$\begin{array}{l}\text { Critical values for (F-sta- } \\
\text { tistics) }\end{array}$ & Lower bound at 5\%=2.62 & & Upper bound at $5 \%=3.79$ \\
\hline
\end{tabular}

Table 3 Long-run estimates

\begin{tabular}{lccc}
\hline Variables & Coefficients & $\boldsymbol{t}$-statistics & $\boldsymbol{P}$-values \\
\hline C & 0.4096 & $3.8612^{* * *}$ & 0.0008 \\
RECEXP & -0.2807 & $-3.6848^{* * *}$ & 0.0013 \\
CAPEXP & 0.0461 & 0.5802 & 0.5677 \\
DEBT & -0.1495 & $-4.0708^{* * *}$ & 0.0005 \\
PRIEXP & 0.1544 & $16.2248^{* * *}$ & 0.0000 \\
INVEST & 0.0013 & $3.5736^{* * *}$ & 0.0017 \\
\hline
\end{tabular}

The superscripts ***,*** and * represent the rejection at $1 \%, 5 \%$ and $10 \%$ levels of significance, respectively. RGDP means, real gross domestic product; RECEXP is, total government recurrent expenditures as a percent of GDP; CAPEXP represents, total government capital expenditures as a percent of GDP; DEBT is total public debt as a percent of the GDP; PRIEXP, denotes private consumption expenditure; INVEST, gross domestic investment as measured by annual growth of gross capital formation

From the bound test results, the estimated $F$-statistic lies above the critical values of the upper bound at the $5 \%$ level of significance indicating the existence of a long-run relationship among our variables and economic growth. We, therefore, proceed to present the long-run coefficients in Table 3.

From the long-run coefficients, government recurrent expenditures have significant negative impacts on economic growth over the period of the study such that if all other factors are held constant, a percent increase in the recurrent spending of government is expected to reduce economic growth by about $0.28 \%$. This result has demonstrated that real economic growth cannot be sustained by excessive recurrent expenditure.

On the other hand, capital expenditure of the government follows the expected sign as it has a positive impact on economic growth. However, the impact is found to be insignificant over the period of the study. Furthermore, expansionary fiscal policy that is hinged upon public debt has a significant negative impact on economic growth in the long-run such that a percentage rise in public debt in relation to the size of the economy is expected to reduce economic growth by an approximate $0.15 \%$ if all other factors are held constant. Ordinarily, public debt may not necessarily create a negative impact on economic growth provided that it is well managed and more importantly if it is directly or indirectly channeled into improving the real sector of an economy. However, in the case of Nigeria, our findings have not come to us as a shock but rather as an indication of the prevailing misappropriation of public funds. There are occasions where loans were taken and the bulk of such loans were used to finance recurrent expenditures coupled with cases of corruption that involve diversion of public funds that are meant for various developmental projects.

Private consumption expenditures have positive and significant impacts on economic growth in Nigeria over the period of the study such that a percent increase in private consumption expenditures is expected to stimulate real economic growth by about $0.15 \%$ when all other factors are held constant. Similarly, gross domestic investment 
Table 4 Error correction estimates

\begin{tabular}{lccc}
\hline Variables & Coefficients & $\boldsymbol{t}$-statistics & $\boldsymbol{P}$-values \\
\hline$C$ & 0.4096 & 7.1395 & 0.0000 \\
$\Delta($ RGDP $(-1))$ & 0.4071 & 3.7658 & 0.0011 \\
$\Delta($ RECEXP $(-1))$ & 0.0503 & 3.5436 & 0.0018 \\
$\Delta($ DEBT $)$ & -0.0105 & -0.5948 & 0.5580 \\
$\Delta($ DEBT $(-1))$ & 0.1049 & 4.5514 & 0.0002 \\
$\Delta($ PRIVEXP) & 0.0969 & 3.6453 & 0.0014 \\
ECM(- 1$)$ & -0.3382 & -6.9568 & 0.0000 \\
$R^{2}$ & 0.80 & & \\
Adjusted $R^{2}$ & 0.75 & & \\
F-statistics & 15.61 & & \\
DW-stat & 1.90 & & \\
$P$-value & 0.0000 & & \\
\hline
\end{tabular}

The superscripts ${ }^{* * *},{ }^{* *}$ and ${ }^{*}$ represent the rejection at $1 \%, 5 \%$ and $10 \%$ levels of significance, respectively. The symbol $\Delta$ denotes a difference operator. RGDP means, real gross domestic product; RECEXP is total government recurrent expenditures as a percent of GDP; CAPEXP represents, total government capital expenditures as a percent of GDP; DEBT is total public debt as a percent of the GDP; PRIEXP, denotes private consumption expenditure; INVEST, gross domestic investment as measured by annual growth of gross capital formation. ECM means error correction term that depicts the speed of adjustment term to the equilibrium path

Table 5 Pairwise Granger Causality Tests results

\begin{tabular}{llllllll}
\hline $\begin{array}{l}\text { Dependent } \\
\text { variables }\end{array}$ & \multicolumn{2}{l}{$\boldsymbol{F}$-statistics } & \multicolumn{7}{l}{$l$} & & \\
\cline { 2 - 7 } & RGDP & RECEXP & CAPEXP & DEBT & PRIVEXP & INVEST & DECISION \\
\hline RGDP & - & 0.21844 & 0.05868 & 0.36665 & $2.62276^{*}$ & 0.65548 & PRIVEXP $\rightarrow$ RGDP \\
RECEXP & 2.27588 & - & 0.67959 & $5.9557^{* * *}$ & 1.08213 & 0.09020 & DEBT $\rightarrow$ RECEXP \\
CAPEXP & 2.35789 & 0.63222 & - & $4.56949^{* * *}$ & 0.85755 & 0.21113 & DEBT $\rightarrow$ CAPEXP \\
DEBT & $2.64269^{*}$ & 2.25369 & 0.95126 & - & $2.75143^{*}$ & 1.43641 & RGDP $\rightarrow$ DEBT \\
PRIVEXP & 1.51849 & 0.19057 & $2.57333^{*}$ & 0.11816 & - & 1.17110 & CAPEXP $\rightarrow$ PRIVEXP \\
INVEST & $6.34559^{* * *}$ & 1.43587 & 1.47908 & $3.71925^{* * *}$ & 1.93285 & - & RGDP $\rightarrow$ INVEST \\
\hline
\end{tabular}

The superscripts ***,** and * represent the rejection at $1 \%, 5 \%$ and $10 \%$ levels of significance, respectively. RGDP means, real gross domestic product; RECEXP is, total government recurrent expenditures as a percent of GDP; CAPEXP represents, total government capital expenditures as a percent of GDP; DEBT is total public debt as a percent of the GDP; PRIEXP, denotes private consumption expenditure; INVEST, gross domestic investment as measured by annual growth of gross capital formation

has a significant positive effect on economic growth in the long-run such that a percent growth in capital accumulation is expected to stimulate growth by about $0.13 \%$ holding all other factors constant.

We set up the error correction model that is associated with our long-run estimates and subsequently obtain the short-run estimates from Eq. (3) as follows:

$$
\begin{aligned}
\Delta \operatorname{RGDP}_{t}= & \gamma_{0}+\sum_{i=2}^{p} \alpha_{1} \Delta \operatorname{RGDP}_{t-i}+\sum_{i=0}^{q} \alpha_{2} \Delta \operatorname{RECEXP}_{t-i}+\sum_{i=0}^{q} \alpha_{3} \Delta \operatorname{CAPEXP}_{t-i} \\
& +\sum_{i=0}^{q} \alpha_{4} \Delta \mathrm{DEBT}_{t-i}+\sum_{i=1}^{q} \alpha_{5} \Delta \operatorname{PRIVEXP}_{t-i}+\sum_{i=0}^{q} \alpha_{6} \Delta \mathrm{INVEST}_{t-i} \\
& +\pi \mathrm{ECM}_{t-1}+\mu_{t} \bigcup_{i=1}^{n} X_{i}
\end{aligned}
$$


where the $(\mathrm{ECM})$ represents the error correction term that measures the speed of adjustment of our model to the long-run equilibrium. The estimated short-run coefficients are provided in Table 4.

The error correction model shows that the short-run disequilibrium will be reconciled in the long-run at an adjustment rate of approximately 34\% annually. Estimates from the error correction model also reveal that recurrent expenditures of the government have a positive impact on the economy in the short-run. In order to understand the nature of the causal relationship among our variables, a Granger Causality Test was conducted and the results are provided in Table 5 .

The F-statistics column shows the long-run Granger Causality Test and "*** and **** represent the rejection of the null hypothesis of no Granger causality among variables at $10 \%, 5 \%$ and $1 \%$ levels of significance, respectively, based on their corresponding $P$-values.

From the Granger Causality result as shown in Table 5, capital expenditure of the government granger causes gross private consumption expenditures in the country over the period of study. If we relate this finding with our long-run estimates that show a positive impact of private consumption expenditures on economic growth in Nigeria, this Granger Causality Test result has provided more support for possible multiplier effects that public spending can create on economic growth. In addition to this, the private consumption spending was also found to be granger causing real economic growth in the country.

Furthermore, fiscal expansion of the government as supported by public debt strongly unilaterally granger causes capital and recurrent expenditures of the government in addition to domestic investment in the country. There is no causality between government expenditures (capital and recurrent) and real GDP, our results have further shown that the size of the Nigerian economy granger causes its public debt over the investigated period. Finally, various diagnostic tests have been carried out to ensure that our estimated model is free from autocorrelation, heteroscedasticity and structural instability as reported in Table 6 :

\section{Table 6 Residual diagnostic test results}

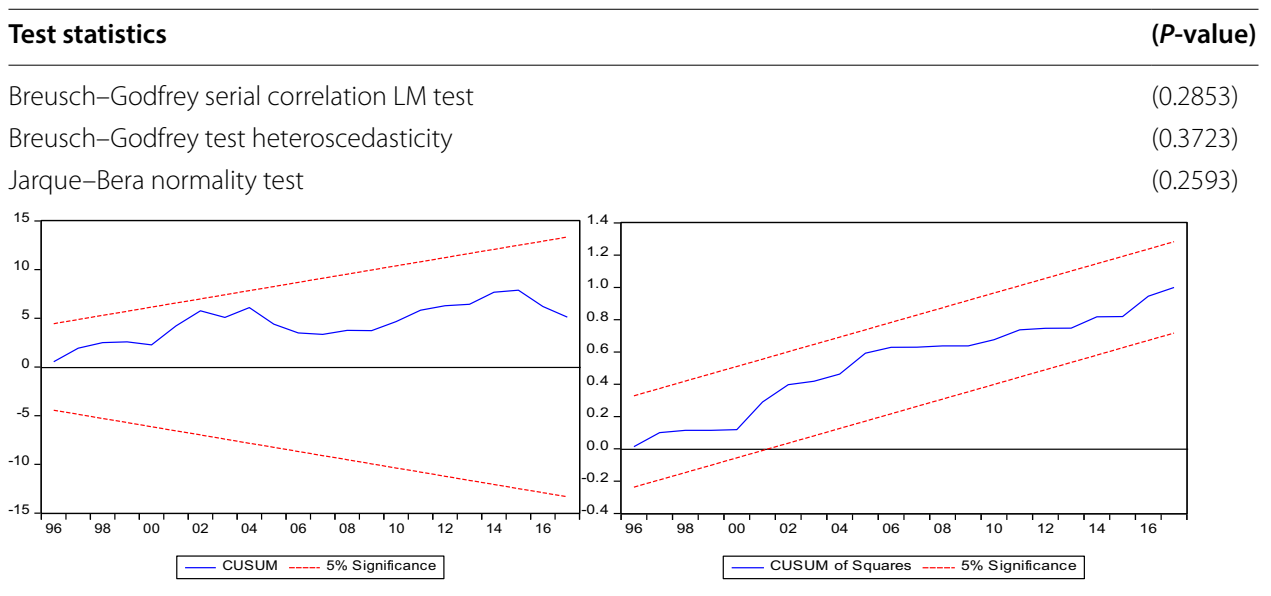

The fitted model satisfactorily pass all the residual diagnostic test. Thus, the model is suitable for policy direction 


\section{Concluding implications and future research directions}

This study has adopted the auto-regressive distributed lag models to examine the impacts of public spending on economic growth in the context of the Nigerian economy from 1981 to 2017. Our findings support the existence of a long-run relationship between economic growth and public expenditures in Nigeria over the period of the study. The results revealed that both recurrent expenditures of the government and public debt have significant negative impacts on economic growth while capital expenditure of the government has a positive, but insignificant impact on the economic growth of the nation in the long-run. The finding is an indication that real economic growth cannot be sustained by humongous recurrent expenditures and fiscal expansion through debt without fiscal discipline and adequate investment in capital projects considering the level of infrastructural deficit in the country. Our result buttresses the findings of Presbitero (2012) that debt and economic growth are significantly and negatively related in developing countries given a certain threshold level which is presently applicable to the Nigerian economy. Further results from the Granger Causality Test reveal that fiscal expansion of the government that is hinged on debt financing is strongly Granger causing public expenditures and domestic investment with the latter also Granger causing real economic growth in Nigeria over the period of our study.

We recommend that the government should ensure that the share of recurrent expenditure in total expenditures is kept within a reasonable proportion by blocking all leakages and wastages in public financing in the country. Some weighty steps that can be taken include merging of some public agencies that have similar functionalities and the review of the disproportionate emoluments given to political public officers to cut down the huge cost of governance among others. Furthermore, in order to adequately harness the expected returns of public capital spending in the economy, the Nigerian government has to be decisive and more transparent in its fight against financial corruption and diversion of public funds especially those that are allocated for the execution of capital projects across the country. Lastly, we cannot but re-emphasize the importance of fiscal discipline in the utilization and disbursement of borrowed funds. We recommend that debt should not be taken by government for the main purpose of financing recurrent expenditures as our findings clearly reveal that public debt granger causes recurrent expenditures in Nigeria over the period of the study.

Future studies can focus on assessing how the established linkages can be complemented with other policy variables in order to engender positive outcomes on economic growth. The suggested future inquiries can be analyzed within the framework of interactive regressions as in contemporary economic development literature (Asongu and Odhiambo 2020a). Moreover, quadratic estimations can also be used to assess specific thresholds at which the engaged variables in the conditioning information set positively affect economic growth (Asongu and Odhiambo 2020b).

Acknowledgements

The authors are indebted to the editor and reviewers for constructive comments that have helped improve the quality of the manuscript.

Authors' contributions

STO was responsible for the conceptual construction of the study. SÇ handled the literature section while SE managed the data gathering, preliminary analysis and simulation alongside SA that proceeded to interpretation of the simulated 
results and the finally author FVB was responsible for proofreading and manuscript editing. All authors read and approved the final manuscript.

\section{Funding}

I hereby declare that there is no form of funding received for this study.

\section{Availability of data and materials}

The data for this present study are sourced from the database of the statistical bulletin of Nigeria CBN (https://www.cbn. gov.ng/) World Development Indicators (https://data.worldbank.org/) and International Monetary Fund data (http:// www.inf.org). (The current data specific data can be made available upon request but all available and downloadable at the earlier mentioned database and web link.)

\section{Competing interests}

The authors declare that they have no competing interests.

\section{Author details}

${ }^{1}$ Department of Economics, Şelcuk University, Konya, Selçuklu, Turkey. ${ }^{2}$ African Governance and Development Institute, P. O. Box 8413, Yaoundé, Cameroon. ${ }^{3}$ Department of Economics and Development Studies, Covenant University, Ota, Ogun State, Nigeria. ${ }^{4}$ Faculty of Economics Administrative and Social Sciences, Istanbul Gelisim University, Istanbul, Turkey. ${ }^{5}$ Department of Accounting, Analysis and Audit School of Economics and Management, South Ural State University, 76, Lenin Aven., Chelyabinsk, Russia.

Received: 17 August 2019 Revised: 8 October 2019 Accepted: 18 January 2020

Published online: 01 February 2020

\section{References}

Abu-Bader S, Abu-Qarn AS (2003) Government expenditures, military spending, and economic growth: causality evidence from Egypt, Israel, and Syria. J Policy Model 25(6-7):567-583

Afonso A, Sousa RM (2011) The macroeconomic effects of fiscal policy in Portugal: a Bayesian SVAR analysis. Portuguese Econ J 10(1):61-82

Alexiou C (2009) Government spending and economic growth: econometric evidence from South-Eastern Europe (SEE). J Econ Soc Res 11(1):1-16

Asongu SA (2014) Linkages between investment flows and financial development: causality evidence from selected African countries. Afr J Econ Manag Stud 5(3):269-299

Asongu SA, Jellal M (2016) Foreign aid fiscal policy: theory and evidence. Comp Econ Stud 58(2):279-314

Asongu SA, Odhiambo NM (2020a) Foreign direct investment, information technology and economic growth dynamics in Sub-Saharan Africa. Telecommun Policy. https://doi.org/10.1016/j.telpol.2019.101838

Asongu SA, Odhiambo NM (2020b) Insurance policy thresholds for economic growth in Africa. Eur J Dev. https://doi. org/10.1057/s41287-019-00234-2

Asongu SA, Folarin OE, Biekpe N (2019a) The long run stability of money demand in the proposed West African monetary union. Res Int Bus Finance 48(April):483-495

Asongu SA, Folarin EO, Biekpe N (2019b) The stability of demand for money in the proposed southern African monetary union. Int J Emerg Mark. https://doi.org/10.1108/IJOEM-08-2018-0443

Auerbach AJ, Gorodnichenko Y (2012) Measuring the output responses to fiscal policy. Am Econ J Econ Policy 4(2):1-27

Backhouse RE (2015) Samuelson, Keynes and the search for a general theory of economics. Italian Econ J 1(1):139-153

Baldacci E, Clements B, Gupta S, Cui Q (2008) Social spending, human capital, and growth in developing countries. World Dev 36(8):1317-1341

Barro RJ (1990) Government spending in a simple model of endogenous growth. J Polit Econ 98:103-125

Beetsma RM, Jensen H (2005) Monetary and fiscal policy interactions in a micro-founded model of a Monetary Union. J Int Econ 67(2):320-352

Bose N, Haque ME, Osborn DR (2007) Public expenditure and economic growth: a disaggregated analysis for developing countries. Manchester School 75(5):533-556

Cecchetti S, Mohanty M, Zampolli F (2011) The real effects of debt. In: BIS working papers

Central Bank of Nigeria, CBN (2017) Statistical Bulletin. Garki: Abuja. https://www.cbn.gov.ng/. Accessed 10 Feb 2019

Claeys P (2006) Policy mix and debt sustainability: evidence from fiscal policy rules. Empirica 33(2-3):89-112

Cooray A (2009) Government expenditure, governance, and economic growth. Comp Econ Stud 51(3):401-418

Cwik, T., and Wieland, V. (2010). Keynesian government spending multipliers and spillovers in the euro area. In: European Central Bank, working paper Series No 1267, ISSN 1725-2806

Dellepiane-Avellaneda S (2015) The political power of economic ideas: the case of 'Expansionary Fiscal Contractions'. Br J Polit Int Relat 17(3):391-418

Egbetunde T, Fasanya OI (2013) Public expenditure and economic growth in Nigeria: evidence from auto-regressive distributed lag underlying. Zagreb Int Rev Econ Bus 16(1):79-92

Fölster S, Henrekson M (2001) Growth effects of government expenditure and taxation in rich countries. Eur Econ Rev 45(8):1501-1520

Günalp B, Gür T (2002) Government expenditures and economic growth in developing countries: evidence from a panel data analysis. METU Stud Dev 29(3-4):311-332

Guseh JS (1997) Government size and economic growth in developing countries: a political-economy framework. J Macroecon 19(1):175-192

Hong S, Nadler D (2015) The impact of political institutions on U.S. state bond yields during crises: evidence from the 2008 credit-market seizure. J Econ Policy Reform 19:77-89 
International Monetary Fund, IMF (2019) https://data.imf.org. Accessed 5 June 2019

Jaramillo L, Cottarelli MC (2012) Walking hand in hand: fiscal policy and growth in advanced economies (No. 12-137). International Monetary Fund

Jhingan ML (1997) Macroeconomic theory. Vrinda Publications Ltd, Delhi

Johnson LE, Ley R, Cate T (2001) Keynes'theory of money and his attack on the classical model. Int Adv Econ Res 7(4):409-418

Nwaka ID, Onifade ST (2015) Government size, openness and income risk Nexus: new evidence from Some African countries (No. WP/15/056). In: AGDI working paper

Okoro AS (2013) Government spending and economic growth in Nigeria (1980-2011). Glob J Manag Bus Res Econ Commer 13:2249-4588

Oteng-Abayie EF (2011) Government expenditure and economic growth in five ECOWAS countries: a panel econometric estimation. J Econ Theory 5(1):11-14

Ouattara B (2006) Foreign aid and government fiscal behavior in developing countries: panel data evidence. Econ Model 23(3):506-514

Pesaran MH, Shin Y (1999) An autoregressive distributed lag modeling approach to cointegration analysis. In: Strom S (ed). Chapter 11-Econometrics and economic theory in the 20th century: the Ragnar Frisch centennial symposium. Cambridge University Press, Cambridge

Pesaran MH, Shin Y, Smith RJ (2001) Bounds testing approaches to the analysis of level relationships. J Appl Econometr 16(3):289-326

Presbitero AF (2012) Total public debt and growth in developing countries. Eur J Dev Res 24(4):606-626

Reinhart CM, Rogoff KS (2010) Growth in a Time of Debt. Am Econ Rev 100(2):573-578

Remmer K (2004) Does foreign aid promote the expansion of government? Am J Polit Sci 48:77-92

Sawyer M (2012) The tragedy of UK fiscal policy in the aftermath of the financial crisis. Camb J Econ 3(1):205-221

Shaikh A (2009) Economic policy in a growth context: a classical synthesis of Keynes and Harrod. Metroeconomica 60(3):455-494

Shelton CA (2007) The size and composition of government expenditure. J Public Econ 91:2230-2260

Shonchoy AS (2010) Determinants of government consumption expenditure in developing countries: a panel data analysis (IDE Discussion Paper No. 266). Chiba, Japan: Institute of Developing Economies, Jetro

Usman A, Mobolaji HI, Kilishi AA, Yaru MA, Yakubu TA (2011) Public expenditure and economic growth in Nigeria. Asian Econ Financial Rev 1(3):104-113

World Development Indicator, WDI (2018) World Bank: Washington, D. C. https://datacatalog.worldbank.org/dataset/ world-development-indicators. Accessed 5 June 2019

Yasin M (2011) Public spending and economic growth: empirical investigation of Sub-Saharan Africa. Southwestern Econ Rev 30:59-68

\section{Publisher's Note}

Springer Nature remains neutral with regard to jurisdictional claims in published maps and institutional affiliations.

\section{Submit your manuscript to a SpringerOpen ${ }^{\circ}$ journal and benefit from:}

- Convenient online submission

- Rigorous peer review

- Open access: articles freely available online

- High visibility within the field

Retaining the copyright to your article

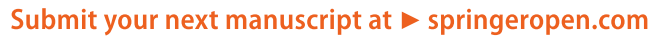

